\title{
高齢者胆囊結石症の自然経過と Ursodeoxycholic
}

\section{acid 経口投与の有用性について}

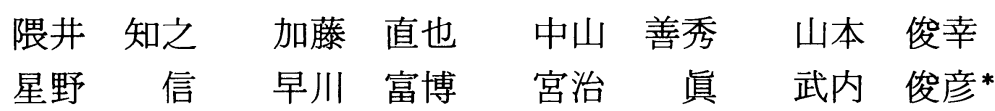

\begin{abstract}
＜要 約＞ 超音波検查の普及により多数の無症状な胆囊結石保有者が発見されているが，その取扱い についてはいまだ一定の見解は得られていない。特に高齢者の場合はその取扱いに際し多数の要因が絡 み, 問題は複雑である.今回われわれは老人医療施設における65歳以上の剖検 1,771 例(男性：女性 $=1$ : 1.2 , 平均年齢 80.2 歳) と 3 年以上経過観察可能であった無症状胆囊結石121例（男性：女性=1:1.9, 平均年齢85.8歳）の胆囊結石保有者を対象として，その臨床経過から高路者胆䪄結石症の取扱いを検討 した。併せて Ursodeoxycholic acid（以下 UDC）の長期経口投与の有用性についても考察した. 剖検例に打ける結石保有率は $16 \%$ ，女性に多く，加齢とともに増加の傾向であった。結石，胆囊癌が 直接死因となった例はわずか $1.8 \%$ であり，結石の有症状化も $3.2 \%$ と低率であった．有症状化による手 術施行率は，UDC 非投与群で $18.9 \%$, UDC 投与群では $6.4 \%$ であった。胆囊造影能はUDC 投与群で改 善例が多くみられ，胆石溶解効果は非石灰化例では $55.9 \%$ と良好であった。 以上より高㱓者胆囊結石症 では，有症状化率や胆石自体のまたは癌合併による死因への関与がきわめて低いため，その取扱いの多 くは経過観察が妥当である。 また, UDC の長期投与は胆石溶解効果の点からばかりでなく, 有症状化の 抑制の面からも有用であると考えられる.
\end{abstract}

Key words : 高齢者, 胆囊結石, 自然経過, 経口溶解療法, Ursodeoxycholic acid

\section{緒言}

近年の超音波検査の普及により，高齢者においても 多数の胆囊結石保有者が無症状で発見されるように なった。しかし，その取扱いについてはいまだ一定の 見解が得られていない．積極的外科治療を主張する立 場からは，高㱓の胆囊結石保有者は疝痛発作などの既 往は少ないが，一旦胆道感染が発症すると重篤化しや

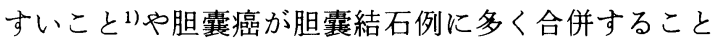
などをその根拠としている．また，保存的治療の立場 からは，高齢者胆囊結石では有症状化が少ないこと， 手術の危険度が高い223) ことなどより, 経過観察が妥当 であるとしている。

今回われわれは，高齢胆霊結石保有者の取扱いを明 らかにする目的で, 老人医療施設における剖検例及び

T. Kumai, N. Katoh, Y. Nakayama, T. Yamamoto: 名古屋市厚生院内科

* S. Hoshino, T. Hayakawa, M. Miyaji, T. Takeuchi : 名古屋市立大学第一内科

受付日：1993。6。10，採用日：1993，7。1
生存例を対象として, 高歯者胆石症の自然経過を検討 した。併せて Urso-deoxycholic acid（以下 UDC) の 長期経口投与の有用性についても考察した。

\section{対象と方法}

名古屋市厚生院における1961年 3 月から1992年 3 月 までの65歳以上の剖検1,771例(男性801例, 女性970例, 平均年齢80.2歳）と 3 年以上経過観察可能であった無 症状胆囊結石121例(男性35例, 女性86例, 平均年路令85.8 歳)を対象とした。経過観察例のうち, UDC 投与 $(300 \sim 600 \mathrm{mg} / \mathrm{day})$ 例は, 3 年以上継続投与可能で あった 47 例（男性 9 例, 女性 38 例, 平均年齢 84.7 歳), （最短投与期間 3 年, 最長投与期間 14 年 11 力, 平均 8 年10カ月）とした。胆石の数，大きさの測定は排泄性 胆囊造影にて行い, 最大径が治療前の70\%以下になっ たものを縮小と判定した。 また, 胆石の溶解効果良好 は結石完全消失例と縮小例を合わせたものとした。

\section{成 績}

（I）剖検例での検討 
1）胆霬結石保有率について（Fig. 1)

全剖検例中 284 例 $(16.0 \%)$ に胆霬結石を認めた。男 女比は $1 ： 1.87$ で女性に多く, 胆石保有率は加齢と共 に増加傾向を認めた。

2）胆石保有者の死因

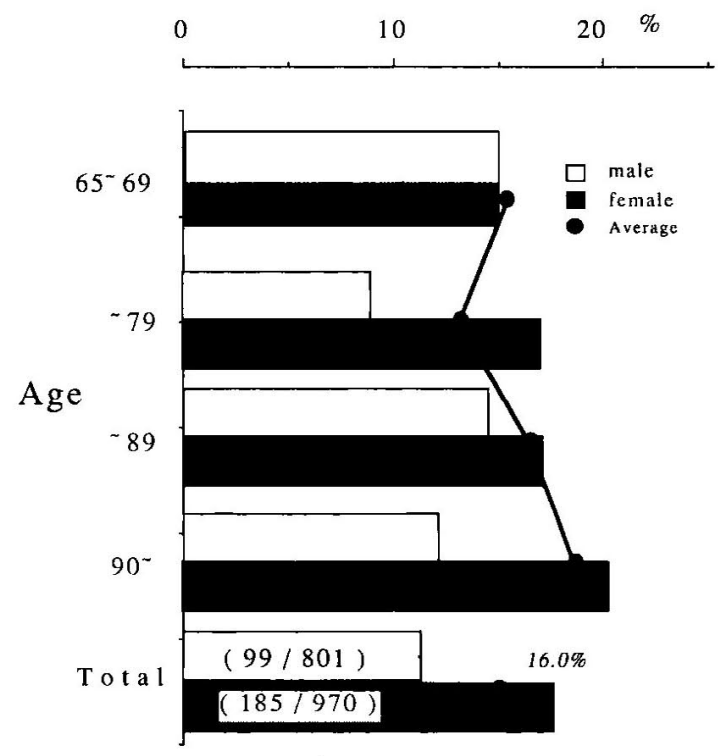

( $284 / 1771)$

Fig. 1 Incidence of gallbladder stones in autopsy cases
死因は呼吸器系良性疾患が $32.4 \%$ と最も多く, 循環 器系疾患が次に続くが, 胆囊結石が死因に直接関与し たと思われる症例は1例（0.4\%）の双であった（Fig. 2). 一方, 胆囊結石保有者の胆囊癌合併率は3.2\%で, 無石例の $1.2 \%$ に比し有意に高率であった $(\mathrm{p}<0.05)$. しかし，胆囊癌が直接死因となったものは有石例で $1.1 \%$ あり，無石例の $0.7 \%$ 比較し有意な差はな かった (Table 1).

\section{3）有症状化とその転帰}

胆石保有者のうち, 胆石によると思われる腹痛, 発 熱, 肝機能異常などが発症し，治療を必要とした症例 を有症状化例とすると，胆襄結石保有者の有症状化は 9 例(3.2\%)と低率であったが，手術例は7例あった。 手術施行時の平圴年齢は76.7歳, 手術後の平均生存 期間119.3力月（9.9年）であった(Table 2). ドレナー ジ例は 1 例のみであり, 発症時82歳で, 胆囊炎が治瘾

Table 1 Frequency of occurrence of gallbladder carcinoma in patients with gallstones

\begin{tabular}{c|c|c|c}
\hline Group & Cases & $\begin{array}{l}\text { Carcinoma of } \\
\text { the gallbladder }\end{array}$ & $\begin{array}{l}\text { Death caused } \\
\text { by cancer }\end{array}$ \\
\hline gallstone $(-)$ & 1487 cases & $\begin{array}{c}18(1.2 \%)- \\
\mathrm{p}<0.05\end{array}$ & $\begin{array}{c}10(0.7 \%)- \\
\text { gallstone }(+)\end{array}$ \\
\hline Total & 1771 cases & $28(1.5 \%)$ & $13(0.7 \%)$ \\
\hline
\end{tabular}

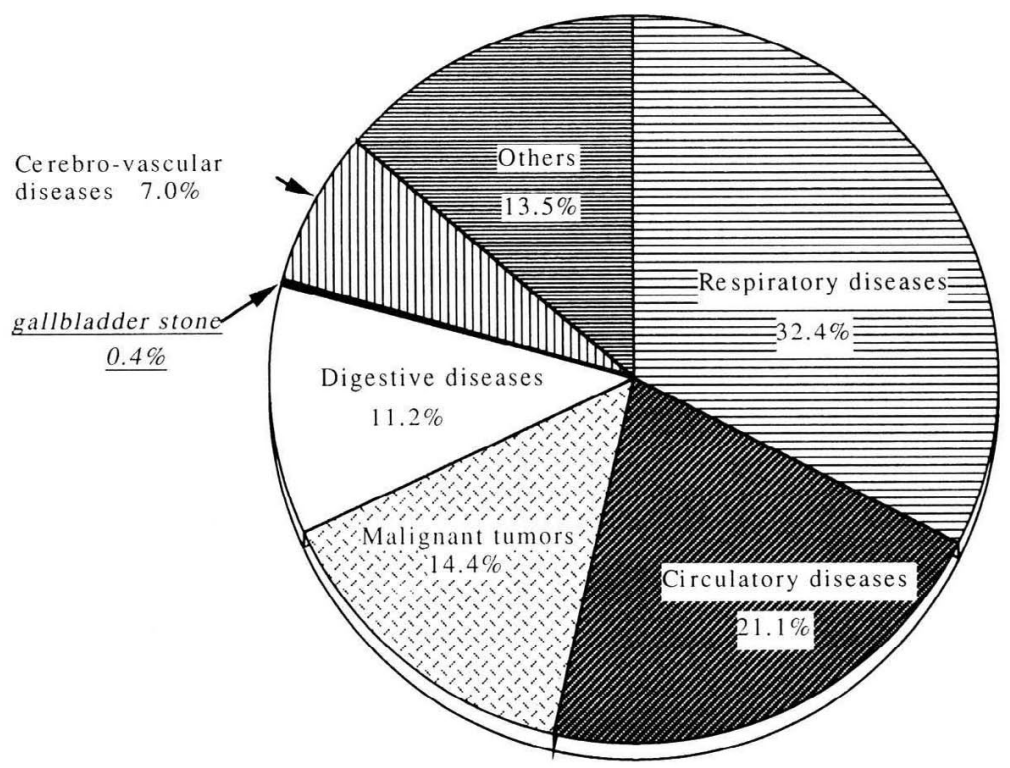

Fig. 2 Causes of death in 284 autopsy cases with gallbadder stones 
Table 2 Prognosis after operation

\begin{tabular}{c|c|c|c|c}
\hline Case No. & Age & $\begin{array}{c}\text { Causes of } \\
\text { operation }\end{array}$ & $\begin{array}{c}\text { Post-operative } \\
\text { survival } \\
\text { (months) }\end{array}$ & Causes of death \\
\hline 1 & 81 & $\begin{array}{c}\text { Right } \\
\text { hypochondralgia }\end{array}$ & 2 & $\begin{array}{c}\text { Miliary } \\
\text { tuberculosis }\end{array}$ \\
\hline 2 & 75 & Cholecystitis & 48 & Pneumonia \\
\hline 3 & 77 & Epigastragia & 108 & $\begin{array}{c}\text { Myocardial } \\
\text { infarction }\end{array}$ \\
\hline 5 & 73 & $\begin{array}{c}\text { Right } \\
\text { hypochondralgia }\end{array}$ & 98 & Lung cancer \\
\hline 6 & 84 & Cholecystitis & 231 & Pneumonia \\
\hline 7 & 73 & Cholecystitis & 168 & Urinary tract \\
infection
\end{tabular}

Table 3 Clinical course of asymptomatic gallstones with or without UDC-treatment (follow up over 3 years)

\begin{tabular}{c|c|c|c|c}
\hline \multirow{2}{*}{ Group } & \multirow{2}{*}{ Cases } & \multicolumn{2}{|c|}{ Symptom } & \multirow{2}{*}{ Operation } \\
\cline { 3 - 4 } & & Symptomatic & Asymptomatic & \\
\hline UDC $(-)$ & 74 & $14\{18.9 \%\}$ & $2\{2.7 \%\}$ & $16(21.6 \%)$ \\
UDC $(+)$ & 47 & $3\{6.4 \%\}$ & $2\{4.3 \%\}$ & $5(10.6 \%)$ \\
\hline Total & 121 cases & 17 cases & 4 cases & 21 cases \\
\hline
\end{tabular}

UDC : ursodeoxycholic acid
した後は経過観察のみで87歳まで生存した。

(II) 経過観察例の検討

1）UDC 投与の有無に抢ける有症状化率 (Table 3) UDC 非投与群では74例中 16 例 $(21.6 \%)$ に手術が施 行されているが，そのらち胆囊炎の発症が手術の契機 となったものが14例あった。一方, UDC 投与群47例で の手術例は 5 例 $(10.6 \%$ ) みられるが, 有症状化のた め手術された例は 3 例 $(6.4 \%)$ のみであった。

2) UDC 投与による結石の变化

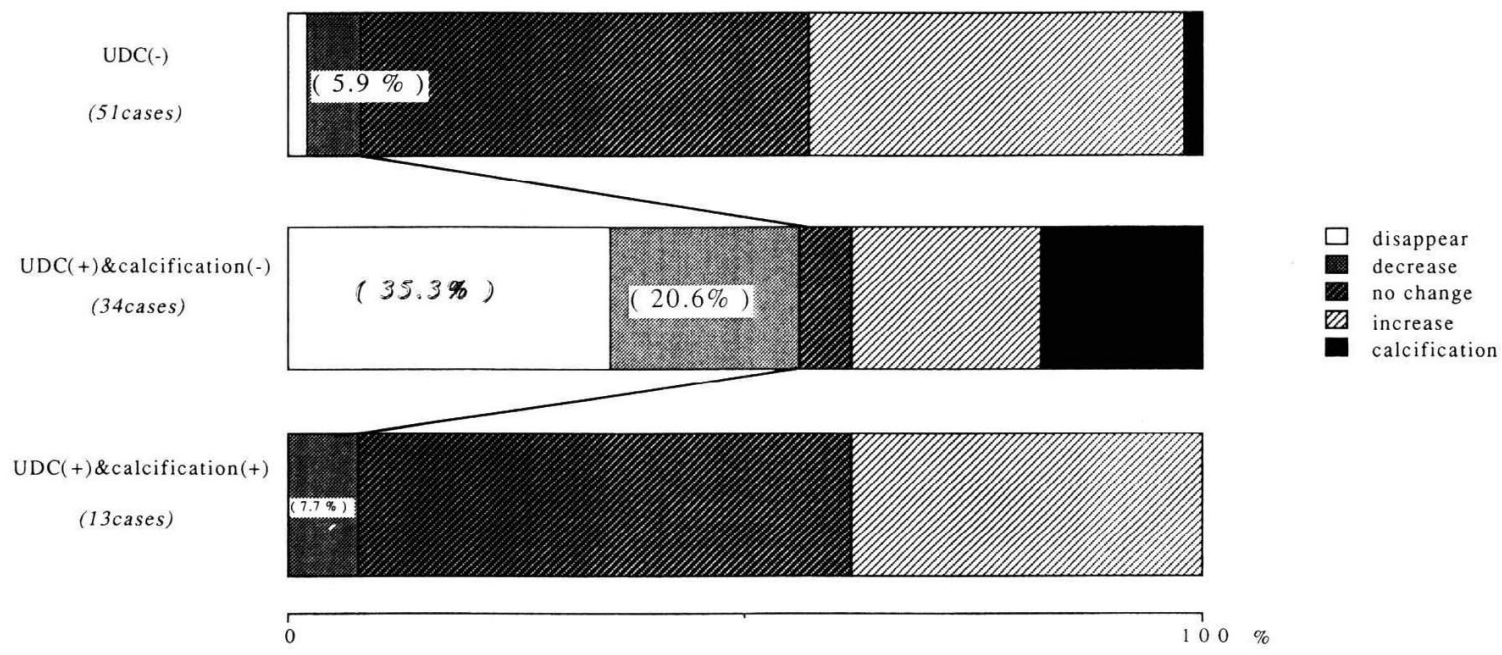

UDC: ursodeoxycholic acid

Fig. 3 Efficacy of UDC dissolution therapy in the presence or absence of gallstone calcification

:disappear, : decrease, : no change, : increase, : calcification 


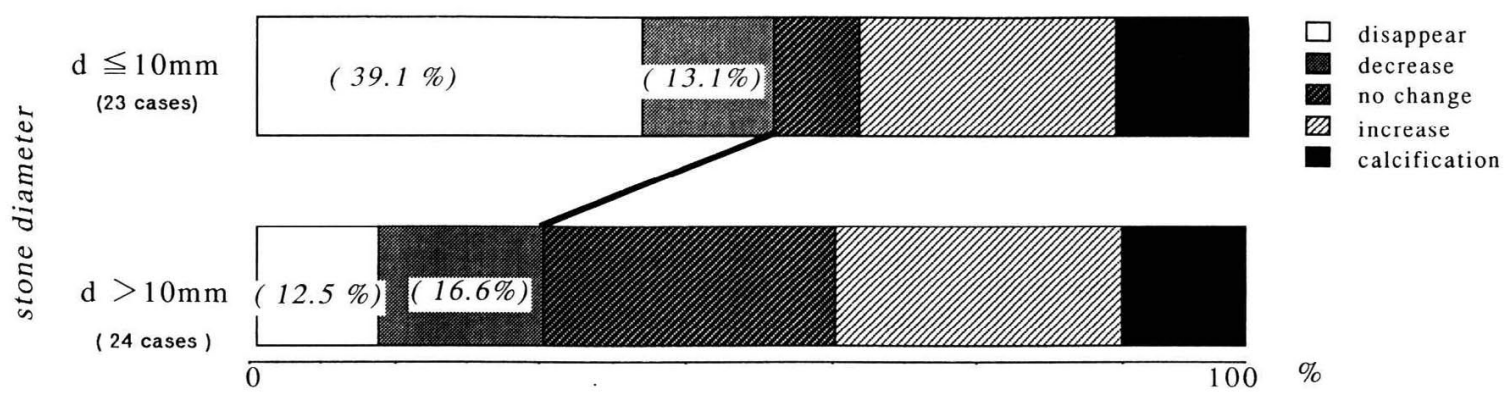

UDC: ursodeoxycholic acid

Fig. 4 Relationship between gallstone diameter and efficacy of UDC treatment (47 cases)

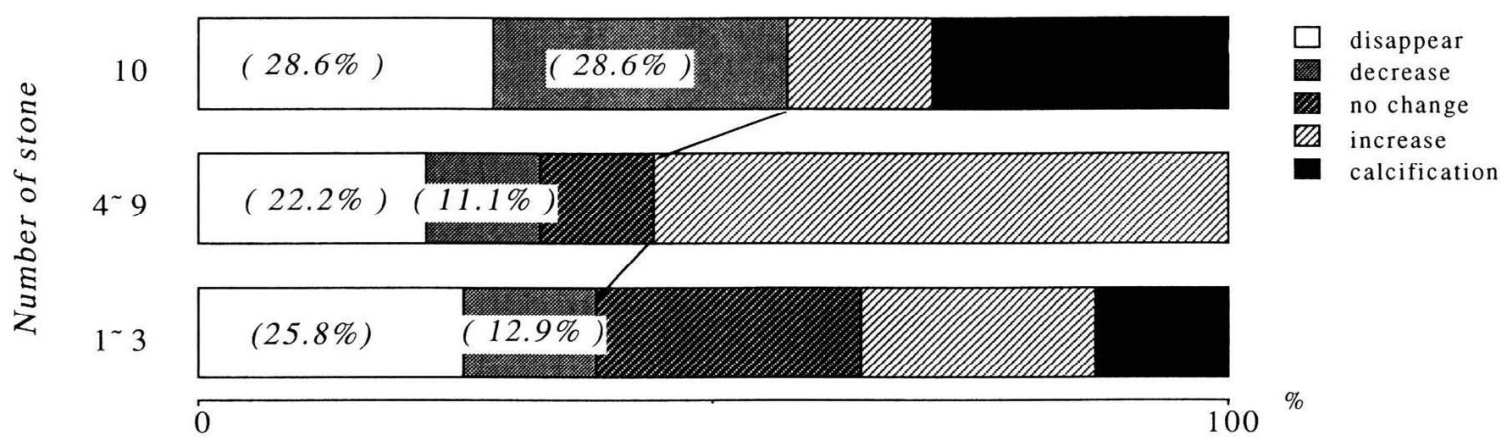

UDC: ursodeoxycholic acid

Fig. 5 Relationship between gallstone numbers and efficacy of UDC treatment (47 cases)
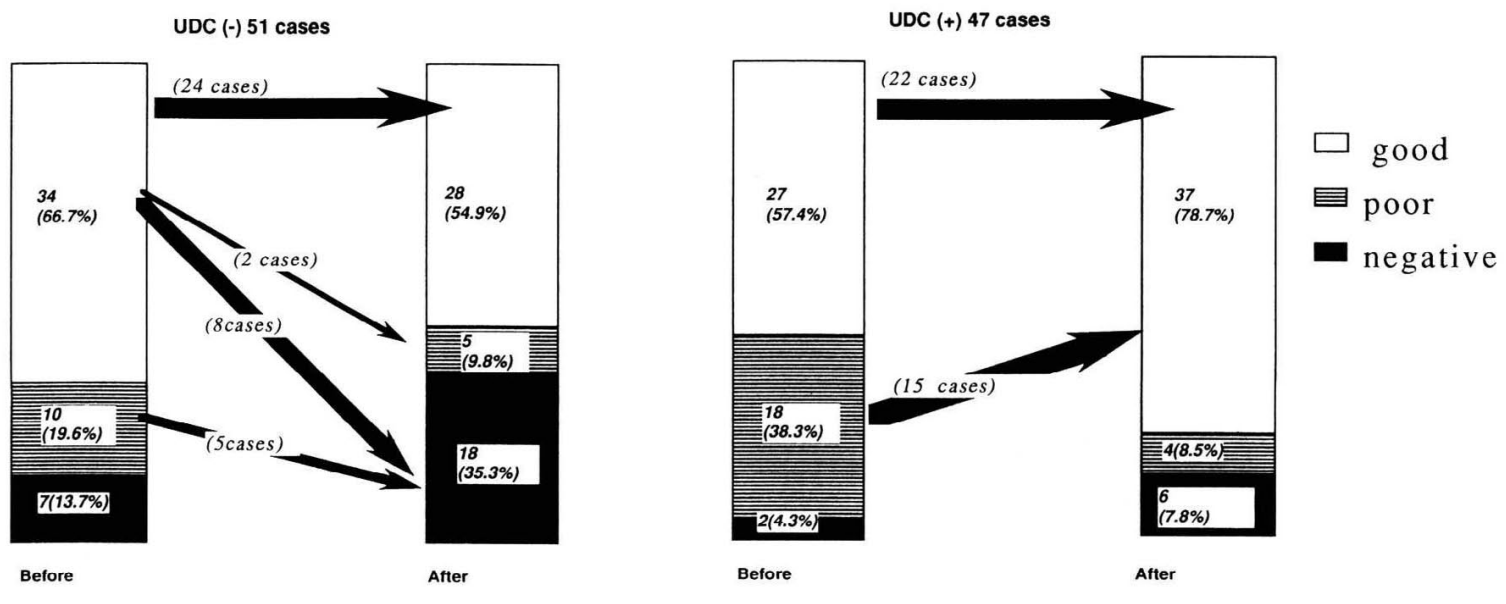

UDC: ursodeoxycholic acid

Fig. 6 Changes in visualization of gallbladder on cholecystogram (follow up : over 3 years) 
排泄性胆豪造影法により 3 年以上にわたり追跡し得 た47例につき, 胆石の大きさ, 個数, 胆囊造影能の変 化について検討した。

a）石灰化の有無からみた溶解効果（Fig. 3)

UDC の溶解効果は石灰化例では完全消失例はなく, 有効率は $7.7 \%$ にどまったが，非石灰化例では12例 (35.3\%)に完全消失を認め，その有効率は $55.9 \%$ 示 した、しかし，治療中の 6 例 $(17.6 \%)$ に新たに結石 の石灰化を認めた。

b) 胆石の大ささからみた溶解効果 (Fig. 4)

最大径 $10 \mathrm{~mm}$ を境に明瞭に 2 分され， $10 \mathrm{~mm}$ 以下で は 9 例 (39.1\%) に完全消失を 3 例に縮小を認め，そ の有効率は $52.2 \%$ あった。一方，10 $\mathrm{mm}$ 以上では $29.2 \%$ 有効率にとどまった。

c) 胆石の個数からみた溶解効果 (Fig. 5)

胆石の個数を 10 個以上, $4 \sim 9$ 個， 3 個以下の 3 グ ループに分けて検討した. 各グループの UDCによる 溶解効果の有効率は各々 $57.2,33.3,38.7 \%$ ありあ, 個数と溶解効果との間には有意な相関はなかった。

3）胆囊造影能の変化（Fig. 6)

3 年以上にわたって追跡し得た 98 例の排泄性胆囊造 影像において, 胆囊造影能の変化をUDC 投与の有無 により比較した。 UDC 非投与51例では, 造影能が良好 から良好が24例, 陰性から不良あるいは良好へ改善し た例は各々 1 例，また，不良より良好への改善例は 2 例のみであった。胆囊造影能良好例34例中 2 例 (5.9\%) が不良化し，8例（23.5\%）は陰性化した。全体では 23例 (45.1\%) が胆囊造影能が改善しないか悪化した。 これに対し, UDC 投与例では胆囊造影能の非改善例あ るいは悪化例は10例（21.3\%）にすぎず，18例中15例 (83.3\%) では造影能が不良から良好へ改善した。

\section{考案}

当院の剖検例における胆囊結石の保有率は, 加齢と 共に増加し, 全体では $16.0 \%$ であり女性で高率であっ た。 また，胆石保有高齢者の有症状化率は $3.2 \%$ ありり， 死因は良性呼吸器疾患や循環器疾患が多かった。 そし て, 胆豊結石が直接的に死因に関与したのは 1 例のみ であった，胆囊結石保有例の胆囊癌の合併頻度につい ては, 報告により大きな差異を認める ${ }^{144) ~ 7) . ~}$ 当院での 検討では有石例で $3.2 \%$, 無石例では $1.2 \%$ に合併がみ られ，有意に有石例の癌合併率が高かった。しかし， われわれは胆石保有高齢者における胆囊癌合併の持つ 臨床的意味は, それが直接の死因となりらるかどうか
によって違ってくると考えている．この観点より，胆 囊癌が直接の死因となった比率について検討すると, 有石例は $1.1 \%$ ，無石例は $0.7 \%$ あり，両者に有意な 差は認めなかった。

無症状胆囊結石の有症状化については従来より多数 の報告がみられる。人間ドックで発見された無症状胆 石を対象にした大藤ら゙の検討では，有症状化率は 5.7\%のみであった。しかし，一般外来を受診した患者 を対象に経過観察した Comfort $ら^{8)}$ や龟田ら 各々 $45 \%, 26.8 \%$ の有症状化率であったと報告してい る.われわれの検討では $3.2 \%$ これらの報告に比しき わめて低值であった。 その理由としては，有症状化の 定義, 観察期間などの違いも考えられるが，最も大き な理由は対象の違いであると思われた。本研究で対象 とした無症状胆石の多くは，老人ホーム入所者を中心 に施行された腹部超音波検査によるスクリーニングに て胆囊結石を発見されたものであり，高齢者の人間 ドックを対象としたものに近いと思われる。以上の検 討より, 高齢胆囊結石保有者では胆囊癌の発生が無石 例に比し高率ではあるが，直接死因となる可能性はき わめて低く, 予防的胆囊摘出術の必要性はないと考光 る。立, 胆囊炎の発症例も低く, たと発症しても 十分な対応が可能と思われる。したがって，高齢者の 無症状胆囊結石患者の取扱いは経過観察が妥当と思わ れる。

コレステロール系胆囊結石に対するUDC の長期経 口投与による胆石の完全溶解率は適応例のおよそ $20 \%$ とされ，低率ではあるが一定の証価が得られている。 しかし, UDC の長期経口投与が胆囊機能に影響を与え ないとする(5)報告がある一方, 胆囊機能を低下さ $世^{11) \sim 14)}$, 特に高㱓者においては胆石の溶解効果が悪い とする ${ }^{15}$ 報告がある。㾂解療法による胆石の変化につ いては, 亀田ら ${ }^{16)}$ は外来通院患者に対して行った検討 にて $8.4 \%$ が消失， $3.8 \%$ が縮小， $32.7 \%$ が増大したと 報告している．今回われわれの検討では，対象が高齢 者であるにもかかわらず, 非石灰化結石では $55.9 \%$ と 高い有効率を認めた. さらに, 溶解効果と結石の大き さ, 個数との関連について詳しく検討すると, 直径が $10 \mathrm{~mm}$ 末満の小結石では消失率が大結石に比し非常に 良好であった。一方，個数と溶解効果との検討では両 者に関連がなかった。この結果により65歳以上の高跲 者においても成人例の報告 ${ }^{17)}$ と同様に溶解効果は結石 の個数にはあまり左右されず, 結石の最大径に関係す る傾向がみられた。しかし，最大径 $10 \mathrm{~mm}$ を超える胆 
石の溶解効果に関しては, 多くの報告がみられる $か^{181 ~ 20)}$, 一定の見解はない(10). 直径 $10 \mathrm{~mm}$ より大きい 結石に対する自験例では, $10 \mathrm{~mm}$ 以下に比し溶解効果 は良くはないが， 3 年以上の長期投与により, 完全消 失 3 例, 縮小 4 例と $29.1 \%$ 有効例があり, 長期投与 と服薬コンプライアンスを保つことが可能な症例で は，10mmより大きい結石も十分適応はあると思われ た。

われわれの UDC 溶解療法の成績は他の報告と比べ てきわめて良好であるが，その理由としては，特殊施 設内に损ける投薬であり，長期投与にもかかわらず服 薬コンプライアンスが良好であったことや大結石に対 しても積極的に投与したことによると思われる。しか し，適応のあるコレステロール系石であっても，すべ てが消失するわけではなく，小さくなった胆囊結石は 胆囊管に嵌頓したり, 総胆管に落下して胆管炎を起こ す可能性もあり, 溶解療法中も腹部超音波検査を中心 とした定期的観察が必要である。

次に胆囊造影能の变化について検討する，無症状胆 石を内科的に管理する上で排泄性胆囊造影法は肝・胆 道系の生理的機能を評価するための簡便で不可欠な検 査である。その造影能の不良化・陰性化は胆囊摘出術 の必要な疾患の存在を示唆する場合もある. 今回の検 討では, 排泄性胆䒼造影能は UDC 非投与51例中 15 例 (29.1\%)に悪化が認められ，前回良好例だった34例中 10例（29.4\%）が造影不良になったり，陰性化してい た。この成績は龟田ら ${ }^{16)}$ の外来患者を対象にした胆囊 造影の陰性化例 $9.6 \%$, 大藤ら ${ }^{211}$ の造影能の变化 $7.4 \%$ よりも高率であった。高齢者の胆箠造影能の老化に伴 う低下は報告されており ${ }^{22)}$ ，このことが UDC 非投与 例の造影能の悪化の要因の一つであると考兄られた。 一方，UDC 投与例は 47 例中 15 例 $(31.9 \%)$ 飞造影能の 改善を認めた。 また, UDC 長期投与により有症状化率 が著減したことは, 高齢者胆囊結石例に対し発症を予 防する治療法としての意味を持つ可能性を示唆したも のと思われる。しかしながら, 胆霊造影能の改善や有 症状化の予防にUDC がぞのような機序で関与してい るかについての詳細は不明である。われわれは以下の ように考学ている. 高齢の胆石保有者は胆汁酸合成能 の低下や腸管運動の低下により一般に胆汁酸プールが 減少している ${ }^{23)}$ と予想されている。 また, 加跉による生 体防御機構の低下之胆汁の分泌能の低下により胆道系 の易感染状態にあると考兄られる。この状態に UDC を投与し胆汁酸プールを増やすと胆汁生成が増加す
る.その結果として, 胆囊への造影剤の流入が増加し 胆囊造影能が改善するのではないかと思われる。また， 胆汁流量の増加は逆行性感染の危険性を減少させ，有 症状化率を低下させると考学ている。

高齢者の胆石症は，溶解療法の適応となる石の割合 は低い17)といわれているが，最近ではコレステロール 系石の割合が増加しており ${ }^{11}$ ，本院でも結石分析を施 行しえた34例中14例（41.2\%）がコレステロール系石 であり，かなりの胆囊結石症例に対しUDC の溶解効 果が期待できると思われる。 また，色素系石に対して もUDC は胆汁分泌を促進することにより感染機会を 低下させると考兄られる。したがって，有症状化防止 の観点からは有用性があると思われる。

\section{結 語}

高齢者においては,

（1）胆囊結石保有率は高いが, 胆囊結石の有症状化, 致死率は極めて低く，また，無石例と比較して胆囊癌 死率に有意な差はなかった。

（2）経口胆石溶解剂により有症状化率は抑制され， 胆囊造影能は改善した。また，高齡者であっても胆石 溶解効果は良好であった。

（3）以上より，高柃者の胆襄結石の取扱いは，絶対 的手術適応例を除き経過観察が妥当である。また，経 口溶解療法の適応例はもちろんのこと, 非適応例につ いても有症状化防止の点からはUDC の長期投与が有 用であると考觉られた。

尚, 本論文の要旨は第34回日本消化器病学会大会にて発 表した。

\section{文献}

1）野呂俊夫, 山城守也, 中山夏太郎, 橋本 肇, 高橋 忠雄, 日野恭徳, 平島得路, 内山周也, 依田一郎, 鈴木祐次郎：高齢者無症状胆石の治療方針。胆と 膵 $1984 ; 5: 1259-1265$.

2) 蜂矢 仁, 早川富博, 宮治 真, 武内俊彦: 高齢者 無症状胆石症の経過と治療。消化器病学の進歩' 85 (太田康幸 編), 日本医学館, 東京, 1985； p256 -257 .

3）早川富博, 宮治 真, 片桐健二, 遠山一太, 友松 武, 伊藤 誠, 武内俊彦, 白井智之, 山本俊幸, 前 田甲子郎：高齢者無症状胆石の臨床病理学的検 討. 日消誌 $1984 ; 81: 2033-2037$. 
4) Newman HF, Northup JD: Gallbladder carcinoma in cholelithiasis - A study of probability 一. Geriatrics $1964 ; 19: 453-455$.

5）伊藤 徹, 出月康夫：無症状胆石の経過と治療方 針一外科の立場から一。消化器外科 $1989 ; 12$ : 1405-1410.

6）柴田耕司, 月江英一, 石原扶美武, 亀田治男 : Silen Stone とその取り扱い方. クリニカ $1985 ; 12$ : 398-402.

7）大藤正雄: 無症状胆石の手術適応. 臨床成人病 $1972 ; 2: 659-663$.

8) Comfort MW, Gray HK, Wilson JM: The silent gallstone: A ten to twenty year follow-up study of 112 cases. Ann Surg 1948; 128 : 931 $-937$.

9）亀田治男, 石原扶美武, 柴田耕治, 月江英一, 高木 一郎, 日原雅文, 山秋拓司, 日野博宣：無症状およ び若年者・高齢者胆石症. 肝胆脺 $1983 ; 7: 995$ -1001 .

10）丹野尚昭, 小泉 勝, 目黒敬義, 阿部直司, 金沢義 彦, 平川秀紀, 豊田隆謙：胆汁酸製剂による経口胆 石溶解療法有効例の臨床的検討, 特に, 大胆石例の 経過と胆囊機能の変化について一, 胆道 1992 ; $6: 380-386$.

11) Malagelda JR, Go Vay LM, Dimagno EP, Summerskill WHJ: Interactions between intraluminal bile acids and digestive products on pancreatic and gallbladder function. J Clin Invest $1973 ; 52: 2160-2165$.

12) Forgas IC, Maisey MN, Murphy GM, Dowling $\mathrm{RH}$ : Influence of gallstones and ursodeoxycholic acid therapy on gallbladder emptying. Gastroenterology $1984 ; 87: 299-307$.

13) Sylwestrowicz TA, Shaffer EA: Gallbladder function during gallstone dissolution, Effect of bile acid therapy in patients with gallstone.
Gastroenterology 1988; $95: 740-748$.

14) Festi D, Frabboni R, Bazzoli F, Sangremano A, Ronchi M, Rossi I, Parini P, Orsini M, Primerano AMM, Mazzella G, Aldini R, Roda E: Gallbladder motility in cholester-ol gallstone disease. Effect of ursodeox-cholic acid administration and gallstone-e dissolution. Gastroenterology $1990 ; 99: 1779-1785$.

15）菅田文夫：胆石溶解療法。現代医療 $1983 ； 14$ ： $2253-2257$

16）亀田治男：胆石症の自然消失について. 最新医学 $1972 ; 27: 1113-1125$.

17）大野孝則, 大藤正雄, 守田政彦, 税戸宏光, 土屋幸 浩, 木村邦夫：経口胆石溶解療法の適用, 副作用な らびに胆石再発について。胆と膵 $1082 ; 3: 1555$ -1562 .

18）柴田久雄, 岡村博文, 国文茂博：Ursodeoxycholic acidによるコレステロール胆石液解の経過及び 消化後の再発に関する検討. 日消誌 $1982 ; 79: 53$ -60 .

19）児島辰也, 渋谷裕史, 福田定男, 斉藤利彦, 芦沢真 六, 初芝澄雄 : 完全溶解例からみた経口胆石溶解 剂の投与期間に関する臨床的検討。医学と薬学 $1989 ; 22: 703-709$.

20）土屋幸浩, 大藤正雄, 税所宏光, 江原正明, 高梨秀 樹, 埴谷一夫：経口胆石溶解療法一溶解例からみ た超音波診断の意義. 胆と膵 $1988 ; 9: 7-16$.

21）大藤正雄 : 無症状性胆石症 (Silent stone) の手術 適応について。 日消誌 $1971 ; 68: 470-472$.

22）宮治 真, 武内俊彦：老年者における消化器疾患. 現代医学 $1981 ; 29: 171-175$

23) Vlahcevic ZR, Bell CC, Buhac I Jr, Farrar JT, Swell L: Diminished bile acid pool size in patients with gallstonees. Gastroenterology $1970 ; 59: 165-173$. 
Abstract

\section{Natural History and URSO Dissolution Therapy of Gallbladder Stones in the Elderly}

Tomoyuki Kumai, Naoya Katoh, Yoshihide Nakayama, Toshiyuki Yamamoto*, Tomihiro Hayakawa, Makoto Hoshino Makoto Miyaji and Toshihiko Takeuchi**

To determine how to treat silent gallstones in the elderly, 1771 autopsied cases 65 years of age or older were studied retrospectively, and 121 cases with asymptomatic gallbladder stones were followed for over 3 years. Of these, 47 cases treated with urosodeoxycholic acid (UDC) for over 3 years were investigated to determine the efficacy of UDC therapy. In the autopsied cases, the incidence of gallbladder stones was $16 \%$, and increased with age. The ratio of males to females was $1: 1.2$. Only $3.2 \%$ of people with silent gallstones developed symptoms. Autopsy studies showed that the majority of people with gallstones died of unrelated causes such as benign respiratory and circulatory dis-

* Nagoya-shi Kouseiin Geriatric Hospital

** First Department of Internal Medicine, Nagoya City University Medical School eases. Only $1.8 \%$ of patients with gallstones died of acute cholecystitis or gallbladder cartinoma. UDC treatment was effective in $55.9 \%$ of patients with radiolucent stones. The percentage of patients requiring surgery due to becoming symptomatic was much lower $(6.4 \%)$ in UDC-treated patients. The visualization of the gallbladder on cholecystogram improved in cases treated with UDC. These results indicate that elderly patients with silent gallstones generally develop neither symptoms nor carcinoma. Therefore, follow-up management by ultrasonography and cholecystography can be allowed. We also emphasized that a satisfactory response was obtained with long term UDC therapy.

Key words: Elderly people (patients), Silent gallstone, Natural history, Dissolution therapy, Ursodeoxycholic acid

(Jpn J Geriat 1993, 30: 849-856.) 